\title{
THE CROWDING-OUT EFFECT IN A SMALL DEVELOPING ECONOMY: A LESSON FROM COVID-19
}

\author{
DOI: 10.17261/Pressacademia.2021.1432 \\ PAP- V.13-2021(21)-p.99-100
}

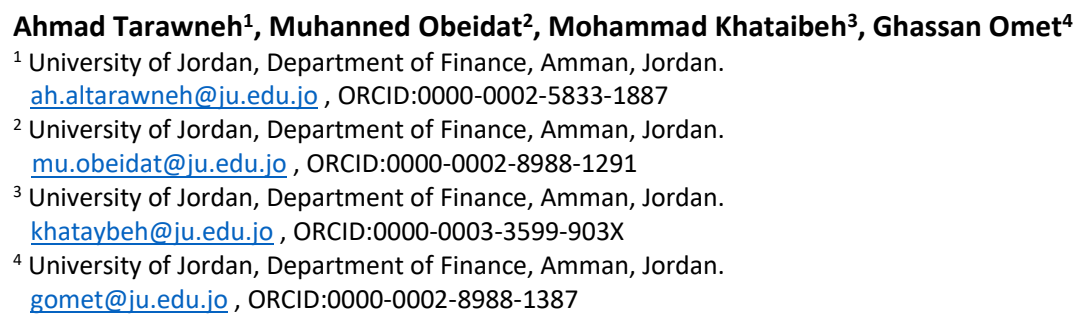

To cite this document

Tarawneh A., Obeidat, M., Khataibeh, M., Omet, G. (2021). The crowding-out effect in a small developing economy: a lesson from Covid-19. PressAcademia Procedia (PAP), V.13, 99-100.

Permanent link to this document: $\mathrm{http}: / /$ doi.org/10.17261/Pressacademia.2021.1432

Copyright: Published by PressAcademia and limited licensed re-use rights only.

\section{ABSTRACT}

Purpose- COVID-19 has dealt a severe blow to public finance, and caused public debt to Gross Domestic Product (GDP) to pass the 100 percent mark. Given this, the objective of this paper is to examine the impact of bank lending to the government on bank credit to the private sector (crowding-out effect) in Jordan.

Methodology- This paper uses bank-level data during the period 2011-2020. Based on the collected data from the financial statements of all 13 conventional Jordanian banks, the Seemingly-Unrelated Regression (SUR) is applied to examine the determinants of their credit growth. The used independent variables are bank deposit growth, credit to the government, bank size, bank capital, bank income diversification, real economic growth, and inflation rate.

Findings- The 2020 financial statements show that the profits of Jordanian banks (return on assets) have decreased from 1.43 percent in 2019 to 0.74 percent in 2020. This decrease was mainly due to the increase in loan loss provisions. As far as the econometric results are concerned, it is informative to note that the impact of banks' lending to the government, in the form of government securities, is negative and significant, and in all estimated econometric versions.

Conclusions- While much of the determinants of bank performance are applicable to the Jordanian scene, it is encouraging to note that Jordanian banks have managed to finish the 2020 financial year well. However, it is argued that the government should use COVID-19 as a "trigger" point for change in the status of its poor public finance.

Keywords: Jordan, banks, profitability, net interest margin; bank size; seemingly-unrelated regression.

JEL Codes: G20, G21, G24.

\section{REFERENCES}

Akpansung, A. (2018). Analysis of the impacts of domestic debts on private sector credit, lending rate, and real output: Evidence from Nigeria. Journal of Finance and Economics, 6, 111-123.

Arestis, P. and Demetriades, P. (1997). Financial development and economic growth: Assessing the evidence. The Economic Journal, 107, 783-799,

Awdeh, A. (2017). The determinants of credit growth in Lebanon. International Business Research, 10, 9-19.

Berger, A. and Bouwman, C. (2009). Bank liquidity creation. Review of Financial Studies, 22, 3779-3837.

Burriel, P., Checherita-Westphal, C., Jacquinot, P., Schon, M. and Stahler, N. (2020). Economic consequences of high public debt: Evidence from three large scale DSGE models. European Central Bank Working Paper No. 2450.

Ben Moussa, M. and Chedia, H. (2016). Determinants of bank lending: Case of Tunisia. International Journal of Finance and Accounting, 5, 27-36 Coval, J. and Thakor, A. (2005). Financial intermediation as a beliefs-bridge between optimists and pessimists. Journal of Financial Economics, 75 , 535-569. 
Huybens, E. and Smith, B. (1999). Inflation, financial markets and long-run real activity. Journal of Monetary Economics, 43, 283-315

Ivanovic, M. (2016). Determinants of credit growth: the case of Montenegro. Journal of Central Banking Theory and Practice, 2, $101-118$.

Lee, M.-w., \& Goh, K.-I. (2019). Bond market development in Malaysia: Possible crowding-out from persistent fiscal deficits? Economics Bulletin, 39, 1798-1807.

Lidiema, C. (2018). Effects of government borrowing on private investments in Kenya. Journal of Finance and Economics, 6, 49-59.

Miyajima, K. (2020). What influences bank lending in Saudi Arabia?. Islamic Economic Studies, 27, 125-155.

Mwakalila, E. (2020). Crowding out of private sector in Tanzania: Government expenditure, domestic borrowing, and lending rates. Emerging Economy Studies, 6, 123-135

Nguyen and Dang (2020). Bank-Specific Determinants of Loan Growth in Vietnam: Evidence from the CAMELS Approach. Journal of Asian Finance, Economics and Business, 7, 179-189.

Ostry, J., Ghosh, A. and Espinoza. R. (2015). When should public debt be reduced, International Monetary Fund, Staff Discussion Note 15/10.

Woo, J. and Kumar, M. S. (2015): Public debt and growth. Economica, 82: 705-739. 